\title{
Review on Sects and Religions in History of Iraq
}

\author{
Muayad Baqer Mohammed Alfahham \\ Lecturer in Contemporary Islamic History Field \\ Department of Power Mechanics \\ Najaf Engineering Technical College \\ Alfurat Al-awsat Technical University, Iraq \\ E-mail:coj.mua@atu.edu.iq
}

\begin{abstract}
Every tribe in Iraq has (Sunnis ,Sheia, the Yazidis, Turkmen, Armen,...) in its ranks. Every town and city have a mix of communities. My experience of Iraq, and that of all friends and relatives, is that of an amazing mix of coexisting communities, despite successive divide-and-rule regimes. For many centuries Iraq has been able to allow a religious, cultural and ethnic diversity to exist. Marred and disfigured as it undoubtedly has been from time to time by savage sectarian outbursts it has managed to stand the test of time. And now in a matter of months it is being swept away probably forever in an unimaginably brutal way. This is not only a terrible tragedy for each of those involved it is an historic tragedy for the world as yet another part of the finely woven tapestry of human complexity and coexistence is ripped to shreds. It is easier and quicker by far to destroy, and to call for destruction, than it is to build.
\end{abstract}

\section{Keywords: City, Century, Mix.}

\section{Introduction}

Iraq has been a Muslim-majority country since the time period surrounding the Prophet Muhammad's death. As such, the cultural and national identity of the country is deeply shaped by the religion. Faith in Islam is expressed on a daily basis in Iraq, through dress, dietary codes, regular prayers and language. For example, an Iraqi man who is dedicated to Islam in politics and society may grow their beard quite long to indicate their religious association. Reverence to Allah is also very evident in the way many people speak; it is common to slip praise into casual conversation. The Iraqi Muslim population is particularly complex as it has large populations of followers from both the Sunni and Shi'a sect. It is estimated that 55-60\% of the population is Shi'a whilst roughly $40 \%$ are Sunni Muslims. Indeed, Iraq is the only Arab state in which Shi'a Muslims constitute the majority. However, many Sunnis dispute their minority status, and do not trust religious estimates. Most Shi'a Muslims are ethnically Arab, but there are some Turkomen and Kurdish Shi'a Muslims as well. Of the Sunni Muslim population, it is estimated $60 \%$ Arabs, $37.5 \%$ are Kurds, and $2.5 \%$ are Turkomen. ${ }^{2}$

\section{I.I Islam in Iraq}

Iraq's Arab population is divided between Sunni Muslims and the more numerous Shi i Muslims. These groups, however, are for the most part ethnically and linguistically homogenous, and—as is common throughout the region-both value family relations strongly. Many Arabs, in fact, identify more strongly with their family or tribe (an extended, patrilineal group) than with national or confessional affiliations, a significant factor contributing to ongoing difficulties in maintaining a strong central government. This challenge is amplified by the numerical size of many extended kin groups — tribal units may number thousands or tens of thousands of members - and the consequent political and economic clout they wield. Tribal affiliation among Arab groups has continued to play an important role in Iraqi politics, and even in areas where tribalism has eroded with time (such as major urban centres), family bonds have remained close. Several generations may live in a single household (although this is more common among rural families), and family-owned-and-operated businesses are the standard. Such households tend to be patriarchal, with the eldest male leading the family. 


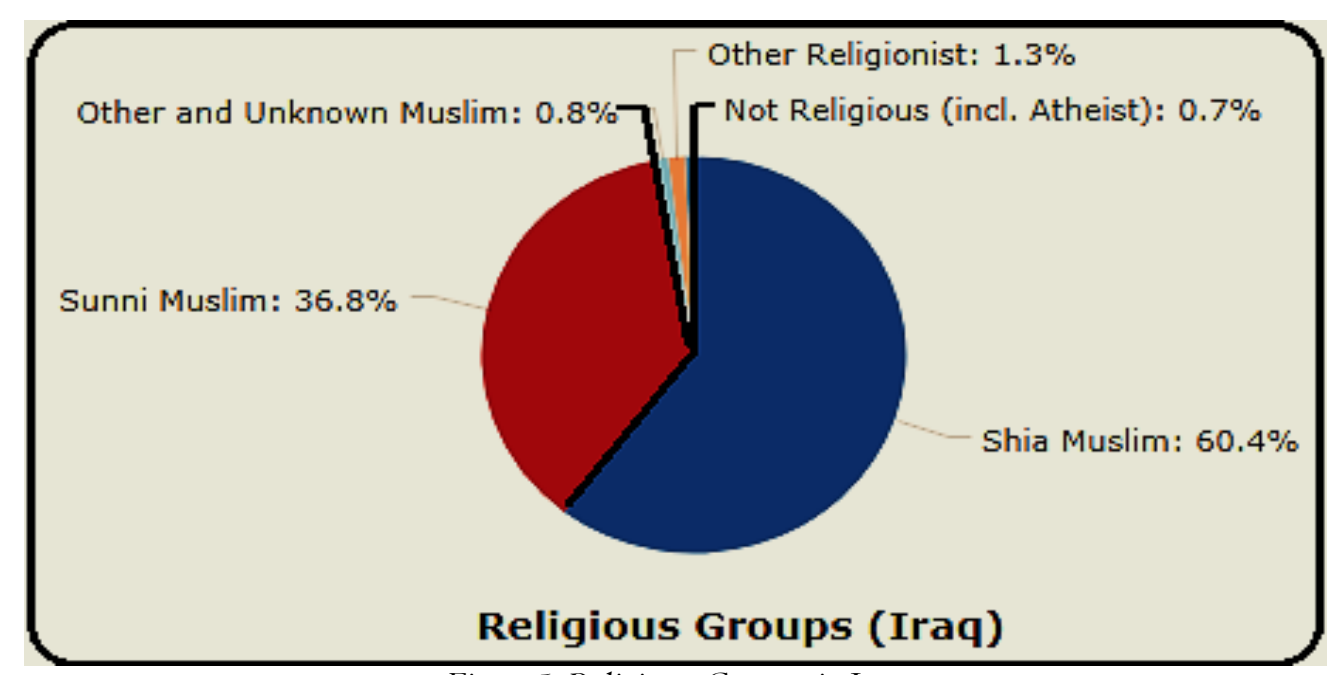

Figure I. Religious Groups in Iraq

\section{I.2 Religion of Iraq}

Iraq is predominantly a Muslim country, in which the two major sects of Islam are represented more equally than in any other state. About three-fifths of the population is Shi ${ }^{i} i$, and about two-fifths is Sunni. Largely for political reasons, the government has not maintained careful statistics on the relative proportion of the Sunni and Shi ' $\mathrm{i}$ populations. Shi' is are almost exclusively Arab (with some Turkmen and Kurds), while Sunnis are divided mainly between Arabs and Kurds but include other, smaller groups, such as Azerbaijanis and Turkmen.

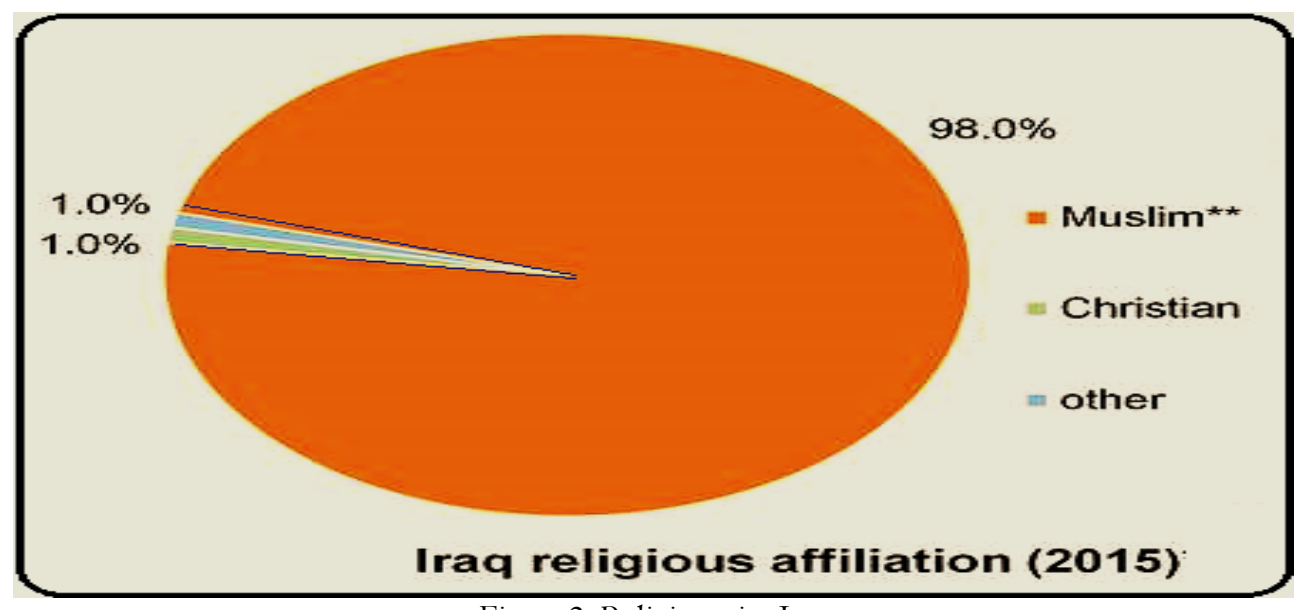

Figure 2. Religious in Iraq

\section{I.3 The Sunnis}

From the inception of the Iraqi state in 1920 until the fall of the government of Sadaam Hosain in 2003, the ruling elites consisted mainly_although not exclusively_of minority Sunni Arabs. Most Sunni Arabs follow the Hanafi school of jurisprudence and most Kurds the Shāfi $1 \overline{1}$ school, although this distinction has lost the meaning that it had in earlier times.

\section{I.4 The Sheia}

The Iraqi Shi' ah, like their coreligionists in Iran, follow the Ithnā 'Asharī, or Twelver, rite, and, despite the preeminence of Iran as a Shi' i Islamic republic, Iraq has traditionally been the physical and spiritual centre of Shi 'ism in the Islamic world. Shi 'ism's two most important holy cities, Najaf and Karbala, are located in southern Iraq, as is Küfah, sanctified as the site of the assassination of 'Alī, the fourth caliph, in the 7th century. Sāmarrā', farther north, near Baghdad, is also of great cultural and religious significance to the Shi 'ah as the site of the life and disappearance of the I2th, and eponymous, imam, Muhammad alMahdī al-Hujjah. In premodern times southern and eastern Iraq formed a cultural and religious meeting place between 
the Arab and Persian Shi i $i$ worlds, and religious scholars moved freely between the two regions. Even until relatively recent times, large numbers of notable Iranian scholars could be found studying or teaching in the great madrasahs (religious schools) in Najaf and Karbala. The Iranian cleric Ayatollah Ruhollah Khomeini, for instance, spent many years lecturing at Najaf while in exile. Although Sheia constituted the majority of the population, Iraq's Sunni rulers gave preferential treatment to influential Sunni tribal networks, and Sunnis dominated the military officer corps and civil service. Sheia remained politically and economically marginalized until the fall of Sadaam Hosain's regime. Since the transition to elective government, Sheia factions have wielded significant political power.

\section{I.5 Kurds (Kurdish)}

Although estimates of their precise numbers vary, the Kurds are reckoned to be the fourth largest ethnic group in the Middle East, following Arabs, Turks, and Persians. There are important Kurdish minorities in Iraq, Iran, Turkey, and Syria, and Iraq's Kurds are concentrated in the relatively inaccessible mountains of Iraqi Kurdistan, which is roughly contiguous with Kurdish regions in those other countries. Kurds constitute a separate and distinctive cultural group. They are mostly Sunni Muslims who speak one of two dialects of the Kurdish language, an Indo-European language closely related to Modern Persian. They have a strong tribal structure and distinctive costume, music, and dance.

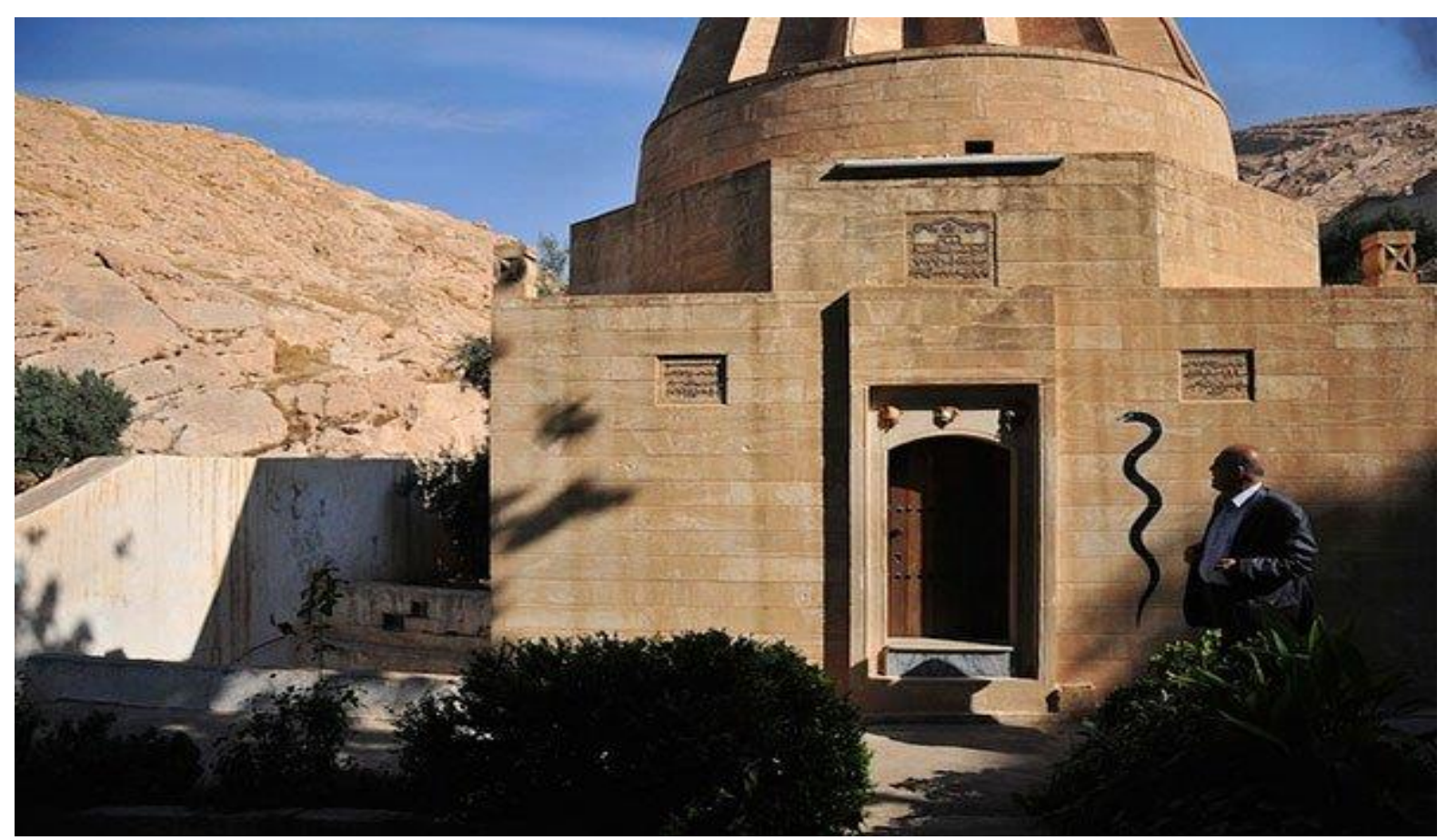

Figure 3. Kurdish religion

The Kurdish people were thwarted in their ambitions for statehood after World War I, and the Iraqi Kurds have since resisted inclusion in the state of Iraq. At various times the Kurds have been in undisputed control of large tracts of territory. Attempts to reach a compromise with the Kurds in their demands for autonomy, however, have ended in failure, owing partly to government pressure and partly to the inability of Kurdish factional groups to maintain a united front against successive Iraqi governments. From I96I to 1975, aided by military support from Iran, they were intermittently in open rebellion against the Iraqi government, as they were during the Iran-Iraq War in the I980s and again, supported largely by the United States, throughout the 1990s.

After its rise to power, the $\mathrm{Ba}$ 'th regime of Sadaam Hosain consistently tried to extend its control into Kurdish areas through threats, coercion, violence, and, at times, the forced internal transfer of large numbers of Kurds. Intermittent Kurdish rebellions in the last quarter of the 20th century killed tens of thousands of Kurds-both combatants and noncombatants-at the hands of government forces and on various occasions forced hundreds of thousands of Kurds to flee to neighbouring Iran and Turkey. Government attacks were violent and ruthless and included the use of chemical weapons against Kurdish civilians; such incidents took place at the village of Halabjah and elsewhere in 1988. 
Following a failed Kurdish uprising in the wake of the Persian Gulf War, the United States and other members of the coalition that it led against Iraq established a "safe haven" for the Kurds in an area north of latitude $36^{\circ} \mathrm{N}$ that was under the protection of the international community. Thereafter the Kurds were largely autonomous. Kurdish autonomy is upheld in the 2005 constitution, which designates Kurdistan as an autonomous federal region.

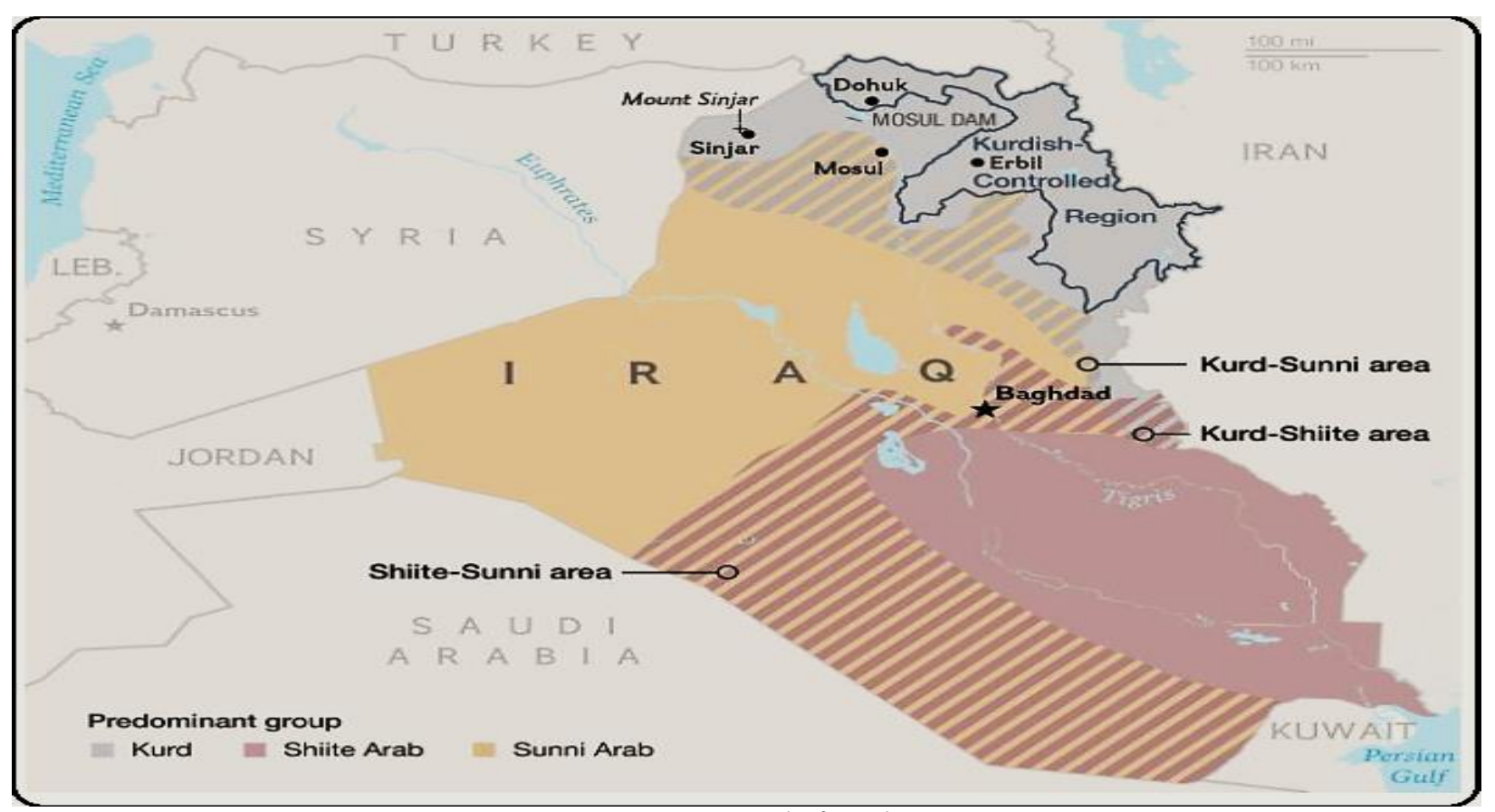

Figure 4. Spread of Kurds

\section{I.6 The Iazidis}

Estimates put the global number of Yazidis at around 700,000 people, with the vast majority of them concentrated in northern Iraq, in and around Sinjar.

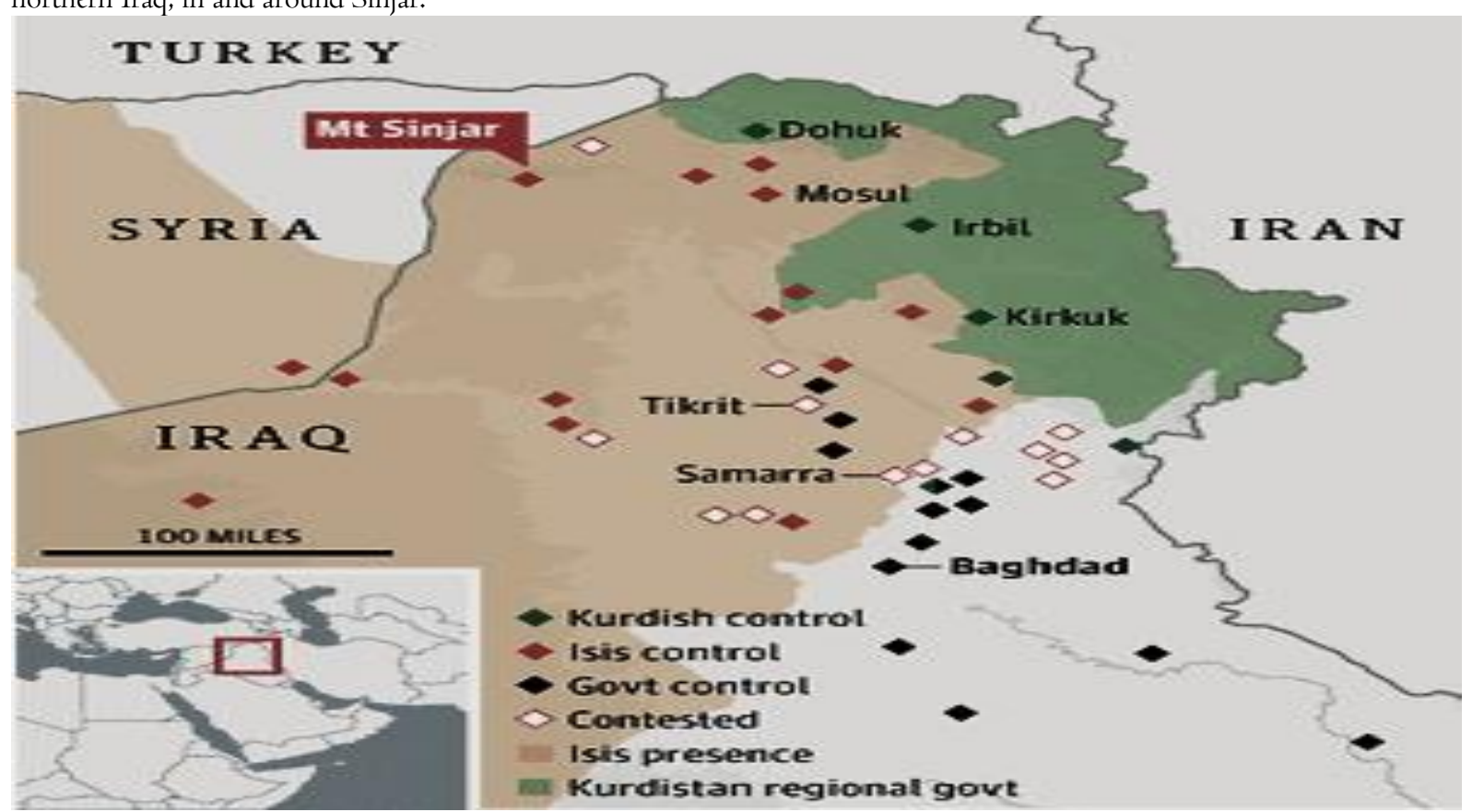

Figure 5. The Iazidis around Sinjar 
A historically misunderstood group, the Yazidis are predominantly ethnically Kurdish, and have kept alive their syncretic religion for centuries, despite many years of oppression and threatened extermination. The ancient religion is rumoured to have been founded by an IIth century Ummayyad sheikh, and is derived from Zoroastrianism (an ancient Persian faith founded by a philosopher), Christianity and Islam. The religion has taken elements from each, ranging from baptism (Christianity) to circumcision (Islam) to reverence of fire as a manifestation from God (derived from Zoroastrianism) and yet remains distinctly non-Abrahamic. This derivative quality has often led the Yazidis to be referred to as a sect.

At the core of the Yazidis' marginalization is their worship of a fallen angel, Melek Tawwus, or Peacock Angel, one of the seven angels that take primacy in their beliefs. Unlike the fall from grace of Satan, in the Judeo-Christian tradition, Melek Tawwus was forgiven and returned to heaven by God. The importance of Melek Tawwus to the Yazidis has given them an undeserved reputation for being devil-worshippers - a notoriety that, in the climate of extremism gripping Iraq, has turned lifethreatening. Under Ottoman rule in the I8th and 19th centuries alone, the Yazidis were subject to 72 genocidal massacres. More recently in 2007, hundreds of Yazidis were killed as a spate of car bombs ripped through their stronghold in northern Iraq. With numbers of dead as close to 800, according to the Iraqi Red Crescent, this was one of the single deadliest events to take place during the American-led invasion.

The Yazidis had been denounced as infidels by Al-Qaida in Iraq, a predecessor of Isis, which sanctioned their indiscriminate killing. The rise of Islamic fundamentalism more broadly has pushed thousands of Yazidis to seek asylum in Europe. According to some estimates, 70,000 people, or about 15\% of the Yazidi population in Iraq, fled the country. For a religion that does not accept converts and strongly discourages exogamy, the assimilation of Yazidi youth in Europe threatens the faith's continued existence. "People have gone out of fear of attacks or fear of racism. This makes it hard to protect the faith," said Baba Sheikh.

\section{I.7 Other Minorities}

Small communities of Turks, Turkmen, and Assyrians survive in northern Iraq. The Lur, a group speaking an Iranian language, live near the Iranian border. In addition, a small number of Armenians are found predominantly in Baghdad and in pockets throughout the north.

Tragic that it took a vicious tyrant to bring about and enforce religious tolerance and one of the highest degrees of gender equality in the Muslim world. While I hated Saddam's regime, I'm inclined to think that he could have been controlled, were it not for the expansionist dream of the neocons, which soon became a nightmare.

\section{I.8 Religious Minorities}

Followers of other religions include Christians and even smaller groups of Yazīdīs , Mandaeans, Jews, and Bahā'īs. The nearly extinct Jewish community traces its origins to the Babylonian Exile (586-5I6 BCE). Jews formerly constituted a small but significant minority and were largely concentrated in or around Baghdad, but, with the rise of Zionism, anti-Jewish feelings became widespread. This tension eventually led to the massive Farhūd pogrom of June I94I. With the establishment of Israel in 1948, most Jews emigrated there or elsewhere. The Christian communities are chiefly descendants of the ancient population that was not converted to Islam in the 7th century. They are subdivided among various sects, including Nestorians (Assyrians), Chaldeans — who broke with the Nestorians in the I6th century and are now affiliated with the Roman Catholic Church-and members of the Syriac Orthodox and Eastern Orthodox churches. About one million Christians lived in Iraq when the Iraq War began. The population has since dwindled to below 250,000, mostly due to poverty and violence by Muslim extremists.

\subsection{The Main Difference Between Sheia and Sunni Muslims}

Both Sunni and Sheia Muslims share the most fundamental Islamic beliefs and articles of faith. The differences between these two main sub-groups within Islam initially stemmed not from spiritual differences, but political ones. Over the centuries, however, these political differences have spawned a number of varying practices and positions which have come to carry a spiritual significance.

The division between Sheia and Sunni dates back to the death of the Prophet Muhammad, and the question of who was to take over the leadership of the Muslim nation. Sunni Muslims agree with the position taken by many of the Prophet's companions, that the new leader should be elected from among those capable of the job. This is what was done, and the Prophet Muhammad's close friend and advisor, Abu Bakr, became the first Caliph of the Islamic nation. The word 'Sunni' in Arabic comes from a word meaning 'one who follows the traditions of the Prophet.'...

The Sheia Muslims believe that following the Prophet Muhammad's death, leadership should have passed directly to his cousin/son-in-law, Ali. Throughout history, Sheia Muslims have not recognized the authority of elected Muslim leaders, choosing instead to follow a line of Imams which they believe have been appointed by the Prophet Muhammad or God Himself. The word 'Sheia' in Arabic means a group or supportive party of people. The commonly-known term is shortened from the 
historical 'Sheia-t-Ali,' or 'the Party of Ali.' They are also known as followers of 'Ahl-al-Bayt' or 'People of the Household' (of the Prophet).

It is important to remember that despite all of these differences in opinion and practice, Sheia and Sunni Muslims share the main articles of Islamic belief and are considered by most to be brethren in faith. In fact, most Muslims do not distinguish themselves by claiming membership in any particular group, but prefer to call themselves simply, 'Muslims.'

\section{Conclusions}

The most serious sectarian and ethnic tensions in Iraq's modern history followed the 2003 US-led occupation, which faced massive popular opposition and resistance. The US had its own divide-and-rule policy, promoting Iraqi organizations founded on religion, ethnicity, nationality or sect rather than politics. Many senior officers in the newly formed Iraqi army came from these organizations and Saddam's army. This was exacerbated from many years ago, when sectarian groups in Syria were backed by the US, Turkey, Saudi Arabia and Qatar

\section{References}

Ammar, J., \& Xu, S. (2018). Who speaks for Islam? Extreme religious groups, the exception that proves the rule. In When Jihadi ideology meets social media (pp. I-16). Cham, Switzerland: Palgrave Macmillan.

Archambault, I., Janosz, M., Dupéré, V., Brault, M. C., \& Andrew, M. M. (2017). Individual, social, and family factors associated with high school dropout among low SES youth: Differential effects as a function of immigrant status. British Journal of Educational Psychology, 87(3), 456-477. doi: I0.I III/bjep.I2159.

Angus Martyn, The Right of Self-Defence under International Law-the Response to the Terrorist Attacks of II September, Australian Law and Bills Digest Group, Parliament of Australia Web Site, I2 February 2002. Archived I6 February 2012 at the Wayback Machine.

Aust, Anthony. (2010). Handbook of International Law (2nd ed.). Cambridge University Press. p. 265. ISBN 978-0-52II3349-4.

Arie W. Kruglanski \& Shira Fishman Current Directions in Psychological Science Vol. I5, No. I (Feb., 2006), pp. 45-48

Bruce Hoffman, Inside Terrorism, 2 ed., Columbia University Press, 2006, p. 34.

Bergen, P., Schuster, C., \& Sterman, D. (2015). ISIS in the West: The new faces of extremism. Washington, DC: New America.

Bates, Benjamin R. (2004).Audiences, Metaphors, and the Persian Gulf War', Communication Studies, 55(3), 447-463.

Beer, Francis A. \& De Landtsheer, Christ'l (2004) 'Metaphors, Politics, and World Politics', in beer, Francis A. and De landtsheer, Christ'l (eds.) Metaphorical World Politics, east lansing: Michigan State university Press, pp. 5-52.

Bhatia, A. (2009) 'The Discourse of Terrorism', Journal of Pragmatics, 4I (2), 279-289.

Burke, Kenneth. (1945). A Grammar of Motives, berkley: university of California Press.

Benjamin, Daniel. (2000). America and the New Terrorism, Survival, 42 (1), 59-75.

Bruce Hoffman (I998). "Inside Terrorism". Columbia University Press. p. 32. ISBN 0-23I-II I668-0. Retrieved January II, 20I0. Google cached copy

Bruce Hoffman (1998). "Inside Terrorism". The New York Times. Retrieved January II, 2010.

Bockstette, Carsten (2008). "Jihadist Terrorist Use of Strategic Communication Management Techniques" (PDF). George C. Marshall Center Occasional Paper Series (20). ISSN 1863-6039. Retrieved January I, 2009.

Bardach, Ann Louis; Rohter, Larry (July 13, 1998). "A Bomber's Tale: Decades of Intrigue". The New York Times. The New York Times Company.

Charteris-Black,Jonathan. (2004). Corpus Approaches to Critical Metaphor Analysis, basingstoke: Palgrave Macmillan.

Chilton, Paul. (1996). Security Metaphors: Cold War Discourse from Containment to Common House, New york: Peter lang.

Chilton, Paul and Lakoff, George. (1999). Foreign Policy by Metaphor, in Schäffner, Christina and Wenden, Anita (eds.) Language and Peace, Amsterdam: Harwood Academic Publishers, pp. 37-59.

Copeland, Thomas. (200I). Is the New Terrorism Really New? An Analysis of the New Paradigm for Terrorism, Journal of Conflict Studies XXi (2), 91-I05.

Craft, Stephanie \& Wanta, Wayne. (2004). 'U.S. public concerns in the aftermath of 9/II: A Test of Second level AgendaSetting', International Journal of Public Opinion Research, I6 (4), 456-463.

Chen, P., Voisin, D. R., \& Jacobson, K. C. (2016). Community violence exposure and adolescent delinquency: Examining a spectrum of promotive factors. Youth \& Society, 48(I), 33-57. doi: I0.II77/0044I I8XI3475827.

Crawford, Joseph (September I2, 2013). Gothic Fiction and the Invention of Terrorism: The Politics and Aesthetics of Fear in the Age of the Reign of Terror. Bloomsbury Publishing. ISBN 978-I-4725-09I2-3.

Crenshaw, Martha (2010). Terrorism in Context. Penn State Press. p. xiii. ISBN 978-0-27I-04442-2. Retrieved February I4, 2019. 
Corrado, Raymond R.; Evans, Rebecca. "Ethnic and Ideological Terrorism in Western Europe". In Stohl, Michael (ed.). The Politics of Terrorism (Third ed.). p. 373. Retrieved February I4, 2019.

Chris Clark "Malayan Emergency, I6 June I948". Archived from the original on June 8, 2007., I6 June 2003.

Committee on the Judiciary, Terroristic Activity: International terrorism; Lester A. Sobel, Political Terrorism; Lauran Paine, The Terrorists (1975).

Downes-Le Guin, Theodore \& Hoffman, Bruce. (I993). The Impact of Terrorism on Public Opinion, I988-I989, Santa Monica: Rand, available at: www.rand.org/pubs/monograph_reports/2006/MR225.pdf [I 5.I I.20I I].

Diaz-Paniagua. (2008). Negotiating terrorism: The negotiation dynamics of four UN counter-terrorism treaties, 1997-2005, p. 47.

Edmund Burke - To The Earl Fitzwilliam (Christmas, 1795.) In: Edmund Burke, Select Works of Edmund Burke, vol. 3 (Letters on a Regicide Peace) (1795). Peleg, Ilan (1988). "Terrorism in the Middle East: The Case of the ArabIsraeli Conflict". In Stohl, Michael (ed.). The Politics of Terrorism (Third ed.). CRC Press. p. 53I. ISBN 978-08247-78I4-9. Retrieved February I4, 2019.

Eviatar, Daphne. (2013). Is 'Terrorism' a War Crime Triable by Military Commission? Who Knows?. Huffington Post. Retrieved From April 29, 2017.

Fine, Jonathan (2010). "Political and Philological Origins of the Term 'Terrorism' from the Ancient Near East to Our Times". Middle Eastern Studies. 46 (2): 27I-288. doi:IO.I080/0026320I0036I9927. JSTOR 20720662.

Fortna, Virginia Page. (2015). Do Terrorists Win? Rebels' Use of Terrorism and Civil War Outcomes. International Organization, 69(3), 5I9-556. doi:I0.I0I7/S00208I83I5000089. hdl:18I I/52898.

Faimau, Gabriel (July 26, 20I3). Socio-Cultural Construction of Recognition: The Discursive Representation of Islam and Muslims in the British Christian News Media. Cambridge Scholars Publishing. p. 27. ISBN 978-I-4438-5I04-6.

Halibozek, Edward P.; Jones, Andy; Kovacich, Gerald L. (2008). The corporate security professional's handbook on terrorism (illustrated ed.). Elsevier (Butterworth-Heinemann). pp. 4-5. ISBN 978-0-7506-8257-2.

Retrieved December 17, 2016.

Heryanto, Ariel(April 7, 2006). State Terrorism and Political Identity in Indonesia: Fatally Belonging. Routledge. p. I6I. ISBN 978-I-I34-I9569-5.

Houen, Alex (September 12, 2002). "Introduction". Terrorism and Modern Literature: From Joseph Conrad to Ciaran Carson. OUP Oxford. ISBN 978-0-19-154198-8.

Hoffman (1998), p. 32, See review in The New York Times Inside Terrorism.

Jenny Teichman. (1989). How to Define Terrorism". Philosophy. 64 (250): 505517. doi:10.1017/S003I8I9I00044260. JSTOR 3751606.

Juergensmeyer, Mark (2000). Terror in the Mind of God. University of California Press. pp. I25-I35.

Khaled, Leila (September 18, I970). "This is Your New Captain Speaking". Life. p. 34. Retrieved February I4, 2019.

Khan, Ali (October 8, 2006). "A Theory of International Terrorism". Connecticut Law Review. I9: 945 - via Social Science Research Network.

Lakoff, George. (1993). The Contemporary Theory of Metaphor', in ortony, Andrew (ed.) Metaphor and Thought (2nd edn), Cambridge: Cambridge university Press, pp. 202-25I.

Laqueur, Walter. (1999). The New Terrorism: Fanaticism and the Arms of Mass Destruction, oxford: oxford university Press.

Lazar, Annita and Lazar, Michelle (2004) 'The Discourse of the New World order: "out Casting” the Double Face of Threat', Discourse \& Society, I5(2-3), 223-242.

Mahon, James E. (1999). Getting your Sources Right. What Aristotle didn't say, in Cameron, lynne and low Graham (eds.) Researching and Applying Metaphor, Cambridge: Cambridge university Press, pp. 69-80.

McCombs, Maxwell E. \& Shaw, Donald L. (1972). The Agenda-Setting Function of Mass Media, The Public Opinion Quarterly, 36(2), I76-I87.

Miller, Joanne M. \& Krosnick, Jon A. (2000). News Media impact on the ingredients of Presidential evaluations: Politically Knowledgeable Citizens Are Guided by a Trusted Source', American Journal of Political Science, 44 (2), 30 I-3 I5.

Milliken, Jennifer. (I999). The Study of Discourse in international Relations: A Critique of Research and Methods', European Journal of International Relations, 5 (2), 225-254.

Mio, Jeffrey S. (1997). Metaphor and Politics', Metaphor and Symbol, I2 (2), I I3-I33.

Malayan People's Anti-Japanese Army Archived March 24, 2007, at the Wayback Machine Britannica Concise.

Muayad Baqer Mohammed Alfahham, Muayad B M. (2020). International Ambitions in Iraq (Petrol, Triggered, other).

Muayad Baqer Mohammed Alfahham, Muayad B M. (2020). Review on Religious Extremism in Islamic History (Previously and Contemporary), Forefront Joumal of Humanities \& Social Science, 2(I), 9- 18 .

Muayad Baqer Mohammed Alfahham, Muayad B M. (2020). The Spread of Terrorism in Contemporary Islamic History with Comparison between Past and Present. 
Nacos, Brigitte (2002) Mass-mediated Terrorism: The Central Role of the Media in Terrorism and Counterterrorism, lanham: Rowman \& Littlefield.

Nacos, Brigitte. (2006). Terrorism and Counter-Terrorism: Understanding Threats and Responses in the Post-9/II World, New york: Pearson, longman.

Norris, Pippa, Kern, Montague and Just, Marion (eds.). (2003). Framing Terrorism. The News Media, the Government and the Public, london: Routledge.

"Number of Terrorist Attacks, Fatalities". The Washington Post. June I2, 2009. Retrieved January II, 20I0. The nation's deadliest terrorist acts - attacks designed to achieve a political goal

Papacharissi, Zizi \& de Fatima Oliveira, Maria. (2008). News Frames Terrorism: A Comparative Analysis of Frames employed in Terrorism Coverage in u.S. and u.K. Newspapers, The International Journal of Press/Politics, I3 (I), 52-74.

Palmer, R.R. (2014). "The French Directory Between Extremes". The Age of the Democratic Revolution: A Political History of Europe and America, I760-I800. The Age of the Democratic Revolution. Princeton University Press. pp. 544567. ISBN 978069II6I280. JSTOR j.ctt5hhrg5.29.

Paul Reynolds; quoting David Hannay; Former UK ambassador (September I4, 2005). "UN staggers on road to reform". BBC News. Retrieved January II, 2010. This would end the argument that one man's terrorist is another man's freedom fighter...

Peter Steinfels (March I, 2003). "Beliefs; The just-war tradition, its last-resort criterion and the debate on an invasion of Iraq". The New York Times. Retrieved January II, 2010. For those like Professor Walzer who value the just-war tradition as a disciplined way to think about the morality of war ...

President Discusses Progress in War on Terrorism to National Guard White House web site 9 February 2006.

Rodin, David (2006). "Terrorism". In E. Craig (Ed.), Routledge Encyclopedia of Philosophy. London: Routledge.

Ronald Reagan, speech to National Conservative Political Action Conference Archived 20 August 2006 at the Wayback Machine 8 March 1985. On the Spartacus Educational web site.

Ruthven, Malise; Nanji, Azim (April 24, 2017). Historical Atlas of Islam. Harvard University Press. ISBN 978-0-674-0I3858.

Radicalisation, De-Radicalisation, Counter-Radicalisation: A Conceptual Discussion and Literature Review. (2016). The International Centre for Counter-Terrorism - The Hague (ICCT). March 27, 2013.

Rediehs, Laura J. (2002). 'evil', in J. Collins and R. Glover, Ross (eds.) Collateral Language. A Users Guide to America's New War. New york: New york university Press, pp. 65-78.

Robert Mackey. (2009). Can Soldiers Be Victims of Terrorism?. The New York Times. Retrieved From January II, 2010. Terrorism is the deliberate killing of innocent people, at random, in order to spread fear through a whole population and force the hand of its political leaders.

Sinclair, Samuel Justin; Antonius, Daniel. (2012). The Psychology of Terrorism Fears. Oxford University Press, US. p. I4. ISBN 978-0-19-5388II-4.

Schmid, Alex. (1989). Terrorism and the Media: The ethics of Publicity, Terrorism and Political Violence, I (4), $539-565$.

Shimko, Keith L. (1994). Metaphors and Foreign Policy Decision Making, Political Psychology, 15 (4), 655-67 I.

Shimko, Keith L. (1995). Foreign Policy Metaphors: Falling “Dominoes” and Drug "Wars”, in lauraNeack, Jeanne Hey \& Patrick Haney (eds.) Foreign Policy Analysis. Continuity and Change in its Second Generation, englewood Cliffs: Prentice Hall, pp. 7I-84.

Simon, Jeffrey. (1987). Misperceiving the Terrorist Threat, RAND Publication Series, R-3423-RC (June), available at: www.rand.org/pubs/reports/2008/R3423.

Sontag, Susan. (1989). Illness as a Metaphor and AIDS and its Metaphors, New york: Doubleday.

Shabad, Goldie; LleraRamo, Francisco Jose (2010). "Political Violence in a Democratic State: Basque Terrorism in Spain". In Crenshaw, Martha (ed.). Terrorism in Context. Retrieved February I4, 2019.

Spencer, Alexander. (2006a). Questioning the Concept of "New Terrorism", Peace Conflict and Development, 8, I-88.

Spencer, Alexander. (2010). The Tabloid Terrorist. The Predicative Construction of New Terrorism in the Media, basingstoke: Palgrave Macmillan.

Sunstein, Cass R. (2003). Terrorism and the Probability Neglect, Journal of Risk and Uncertainty, 26 (2-3), I2I-I36.

Stevenson, ed. by Angus. (2010). Oxford dictionary of English (3rd ed.). New York: Oxford University Press. ISBN 978-019-957I12-3.

Theodore R. (2003). The Metaphor-to Myth Transformation with Special Reference to the "War on Terrorism”, Peace and Conflict: Journal of Peace Psychology, 9 (2), I49-I57.

Tsfati, Yariv \& Weimann, Gabriel (2002) 'www.terrorism.com: Terror on the internet', Studies in Conflict and Terrorism, 25 (5), 317-332.

Terrorism. (2015). Encyclopædia Britannica. p. 3. Retrieved From January 7, 2015. 
The Illusion of War: Is Terrorism a Criminal Act or an Act of War? . Mackenzie Institute. July 31, 20I4. Retrieved from April 29, 2017.

Thackrah, John Richard (2013). Dictionary of Terrorism. Routledge. ISBN 978-I-I35-I6595-6.

Weimann, Gabriel \& Winn, Conrad. (1994). The Theater of Terror. Mass Media and International Terrorism, New york: longman.

Wilkinson, Paul. (2000). Terrorism versus Democracy: The Liberal State Response. london: Frank Cass.

Woods, Joshua. (2007). What We Talk about When We Talk about Terrorism: elite Press Coverage of Terrorism Risk from 1997-2005, The International Journal of Press/Politics, I2 (3), 3-20.

Wisnewski, J. Jeremy, ed. (2008). Torture, Terrorism, and the Use of Violence (also available as Review Journal of Political Philosophy, 6(I). Cambridge Scholars Publishing. p. I75. ISBN 978-I-4438-029 I-8.

White, Jonathan R. (2016). Terrorism and Homeland Security. Cengage Learning. p. 3. ISBN 978-I-305-63377-3.

1994 United Nations Declaration on Measures to Eliminate International Terrorism annex to UN General Assembly resolution 49/60, "Measures to Eliminate International Terrorism", of December 9, I994, UN Doc. A/Res/60/49.

"22 U.S. Code $§ 2656 f$ - Annual country reports on terrorism". LII / Legal Information Institute.

Wibisono S, Louis WR \& Jetten J. (2019). A Multidimensional Analysis of Religious Extremism. Front. Psychol. I0:2560. doi: $10.3389 /$ fpsyg.2019.02560 .

Yusof, N., Kaur, A., Sani, M. A., \& Hashim, R. A. (2019). A Qualitative Expert Interview Approach towards Understanding Religious Extremism among Malaysian Youth. The Qualitative Report, 24(7), I577-I592. Retrieved from https://nsuworks.nova .edu/tqr/vol24/ iss7/5

Yusoufzai, K., \& Emmerling, F. (2017). Explaining violent radicalization in Western Muslims: A four factor model. Joumnal of Terrorism Research, 8(I), 68-80.

Zhang, H., Zhao, J. S., Ren, L., \& Zhao, R. (2017). Subculture, gang involvement, and delinquency: A study of incarcerated youth in China. Justice Quarterly, 34(6), 952-977. doi: I0.I080/07418825.2016.I243254

\section{Copyrights}

Copyright for this article is retained by the author(s), with first publication rights granted to the journal. This is an open-access article distributed under the terms and conditions of the Creative Commons Attribution license (http://creativecommons.org/licenses/by/4.0/). 